\title{
Clinical Significance of TP53 Abnormalities in Newly Diagnosed Multiple Myeloma
}

\author{
Yeni Tanı Multipl Myelomda TP53 Anormalliklerinin Klinik Önemi
}

\author{
(D) Fang Ye1, (D) Tongtong Wang2 ${ }^{2}$ (I) Aijun Liu², (D) Yanchen $\mathrm{Li}^{2}$, (D) Ningning $\mathrm{Li}^{1}$, (D) Huan Wang1, (D) Wenming Chen² \\ ${ }^{1}$ Chuiyangliu Hospital Affiliated to Tsinghua University, Department of Hematology, Beijing, China \\ 2Capital Medical University Beijing Chaoyang Hospital, Department of Hematology, Beijing, China
}

\section{Abstract}

Objective: This study aimed to identify the clinical significance of TP53 and common cytogenetic abnormalities.

Materials and Methods: A total of 114 patients with newly diagnosed multiple myeloma (MM) and TP53 abnormalities were selected from two large patient cohorts of collaborating hospitals from 2010 to 2017. The characteristics and outcomes of these patients were analyzed. TP53 and other common mutations in MM patients were quantified by fluorescence in situ hybridization. Kaplan-Meier curves and logrank tests were applied for survival analysis. A Cox proportional hazard model for covariate analysis was used to determine the prognostic factors.

Results: By extensive data analysis, we found that TP53 amplification is a strong positive predictor for complete response (CR) to therapy and positively correlated with patient survival. The number of simultaneous genomic abnormalities with TP53 mutation has a modest impact on patient survival. Among these mutations, 1q21 amplification is associated with decreased CR (odds ratio: 4.209) and FGFR3 levels are positively correlated with progression-free and overall survival.

Conclusion: TP53 abnormalities at the diagnosis of MM are of great clinical significance in predicting patient response to therapy and survival. Furthermore, $1 q 21$ and FGFR3 mutations could potentially be used in combination with TP53 status to better predict patient survival and guide the selection of high-risk patients to advance patient treatment strategies.

Keywords: TP53, Multiple myeloma, Genomic abnormality

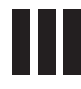

$\ddot{O} z$

Amaç: Bu çalışma, TP53'ün klinik önemini ve yaygın sitogenetik anormallikleri belirlemeyi amaçladı.

Gereç ve Yöntemler: 2010 ile 2017 yılları arasında işbirliği yapan hastanelerin iki büyük hasta grubundan yeni teşhis edilmiş multipl miyelom (MM) ve TP53 anormallikleri olan toplam 114 hasta seçildi. $\mathrm{Bu}$ hastaların özellikleri ve sonuçları analiz edildi. MM hastalarında TP53 ve diğer yaygın mutasyonlar, floresan in situ hibridizasyon ile ölçülmüştür. Hayatta kalma analizi için Kaplan-Meier eğrileri ve logrank testleri uygulandı. Prognostik faktörleri belirlemek amacı ile ortak değişken analizi için bir Cox orantılı tehlike modeli kullanıldı.

Bulgular: Kapsamlı veri analizi ile, TP53 amplifikasyonunun tedaviye tam yanıt (CR) için güçlü bir pozitif öngörücü olduğunu ve hastanın sağkalımı ile pozitif korelasyon gösterdiğini bulduk. TP53 mutasyonu ile eşzamanlı genomik anormalliklerin sayısı, hastanın sağkalımı üzerinde sınırlı bir etkiye sahiptir. Bu mutasyonlar arasında, 1q21 amplifikasyonu, azalmış CR (olasılık oranı: 4.209) ile ilişkilidir ve FGFR3 seviyeleri, progresyonsuz ve genel sağkalım ile pozitif olarak ilişkilidir.

Sonuç: MM tanısındaki TP53 anormallikleri, hastanın tedaviye yanıtını ve sağkalımı öngörmede büyük klinik öneme sahiptir. Ayrıca, 1q21 ve FGFR3 mutasyonları, hasta sağkalımını daha iyi tahmin etmek ve hasta tedavi stratejilerini geliştirmek için yüksek riskli hastaların seçimine rehberlik etmek amacı ile potansiyel olarak TP53 durumu ile kombine halde kullanılabilir.

Anahtar Sözcükler: TP53, Multipl myelom, Genomik anormallik

\section{Introduction}

Multiple myeloma (MM) is a hematologic malignancy caused by the proliferation of plasma cells in the bone marrow. It accounts for approximately $10 \%$ of all hematologic malignancies and $1 \%$ of all cancers $[1,2]$. The tumor plasma cells infiltrate bone marrow and other organs, which leads to lethal immune deficiency and organ damage $[3,4,5]$. Worldwide studies indicate that the incidence of MM has increased by $126 \%$ globally and the 5-year survival rate is only about 50\% [6].

One major factor that contributes to the low survival rate is that MM is a highly heterogeneous disease, characterized by numerous genetic alterations [7]. Chromosome gains and losses,

๑Copyright 2021 by Turkish Society of Hematology

Turkish Journal of Hematology, Published by Galenos Publishing House

口 Hospital, Department of Hematology, Beijing, China

Phone : +86-13910107759

E-mail : 13910107759@163.com ORCID: orcid.org/0000-0003-1788-2460 
immunglobulin $\mathrm{H}$ translocations, and mutations of specific genes are often found in MM patients $[7,8]$. Genetic alterations are categorized as primary or secondary changes based on when the changes are observed during disease progression $[9,10]$. Cytogenetic abnormalities play a very important role in the survival of MM patients. For example, as determined by fluorescence in situ hybridization (FISH) detection, gain (1)(q21), del(17)(p13), and $t(4 ; 14)(p 16 ; q 32)$ in MM patients are correlated with shorter overall survival (OS) $[11,12]$. The fact that the type and quantity of genomic abnormalities are directly linked to MM patients' survival time and response to treatment suggests that an investigation of the role of mutations in predicting patient response and survival is of great clinical significance in $\mathrm{MM}$ patient management [13].

Mapped to the position of chromosome 17p13, the TP53 gene encodes the p53 protein and regulates the cell cycle. Since the discovery of the p53 protein, its role in cancer has been intensively investigated. p53 is an important tumor suppressor due to its critical role in inducing cell cycle arrest and apoptosis in response to cellular stress signals [14].

In MM patients, the major abnormalities of the TP53 gene are mutation and deletion (due to deletion of the $17 p 13$ region). These abnormalities of the TP53 gene rarely occur at diagnosis; they increase in late-stage patients, suggesting the essential role of the TP53 gene in disease progression $[15,16]$. Many clinical reports have shown a strong association between a loss of TP53 and poor prognosis in MM patients $[16,17,18,19]$. However, due to the heterogeneity of $\mathrm{MM}$ and the limited number of cases, the function of TP53 at diagnosis as a biomarker in different backgrounds of the major molecular cytogenetic abnormalities of MM is not well studied. Here, we provide an intensive retrospective analysis of a large cohort of newly diagnosed MM patients to identify the clinical significance of TP53 and common cytogenetic abnormalities. We compare TP53 loss and amplification together with common genes dysregulated in MM patients, including chromosome $1 \mathrm{q} 21$ amplification, translocation of $4 \mathrm{p} 16.3$ (fibroblast growth factor receptor 3, FGFR3), and translocation of 16q23 (MAF) to chromosome $14 q 32$. Investigation of the risk factors of MM relapse/progression will bring insight into the development of adaptive methods for better treatment of MM patients.

\section{Materials and Methods}

\section{Patients}

A total of 1046 newly diagnosed MM patients were enrolled from Beijing Chao-Yang Hospital, the Multiple Myeloma Research Center of Beijing, and Chuiyangliu Hospital Affiliated to Tsinghua University from January 2010 to December 2017. FISH was used to characterize the genetic abnormalities [TP53, 1q21, 14q32/11q13 (CCND1 (cyclin D1 gene)], 14q32/4p16.3
(FGFR3), 14q32/16q23 (MAF) of these patients and diagnostic criteria were based on those of the International Myeloma Working Group [20]. Detailed criteria for FISH positivity are provided in Table 1. Basic patient information including age, gender, habits, baseline health, and comorbid diseases and clinical parameters including OS and chemotherapy response were recorded. The patient selection criterion was a primary diagnosis with TP53 abnormality. Patients were excluded if they had refractory/relapsed MM. The study was approved by the ethics committee of our hospital. All patients gave written informed consent.

\section{FISH}

FISH was performed on interphase cells. CD138-expressing plasma cells were purified and then FISH was performed as previously described [21] using probes purchased from Beijing Hightrust Diagnostic Company Limited. Targets detected by FISH and thresholds are included in Table 1. At least 200 plasma cells were scored to determine the prevalence of each genetic abnormality.

\section{Statistical Analysis}

The primary endpoint of this study was correlated with survival from the time of diagnosis. Progression-free survival (PFS) and OS were evaluated according to the international uniform response criteria [22]. PFS was calculated from the time of diagnosis to the date of death, progression, or last follow-up. OS was defined as the duration from the time of diagnosis to the date of death or last follow-up. Descriptive statistics such as mean, standard deviation, median, and range were used for continuous variables while frequency counts and percentages were used for categorical variables. An independent sample t-test was employed to evaluate the associations between genetic abnormalities and biological parameters. The chi-square test or two-sided Fisher exact test was performed to make comparisons of categorical variables among groups. The Kaplan-Meier method was employed to plot survival curves, with a log-rank test to assess the differences. A Cox proportional hazard model for covariate analysis was used to determine the prognostic factors for PFS. All statistical analyses were performed using SPSS 17.0 (SPSS Inc., Chicago, IL, USA). The results were considered significant at $\mathrm{p}<0.05$.

\begin{tabular}{|l|l|l|}
\hline \multicolumn{2}{|l|}{ Table 1. Summary of FISH positivity thresholds. } \\
\hline Probe & Test site & $\begin{array}{l}\text { Positive threshold } \\
\text { \% cells tested positive }\end{array}$ \\
\hline $1 \mathrm{q} 21$ & $1 \mathrm{q} 21$ & 6.87 \\
\hline TP53 & $17 \mathrm{p} 13.1$ & 6.09 \\
\hline IGH/MAF & $14 \mathrm{q} 32 / 16 \mathrm{q} 23$ & 0.77 \\
\hline IGH/FGFR3 & $14 \mathrm{q} 32 / 4 \mathrm{p} 16.3$ & 1.11 \\
\hline IGH/CCND1 & $14 \mathrm{q} 32 / 11 \mathrm{q} 13$ & 4.85 \\
\hline
\end{tabular}




\section{Results}

The median follow-up time for the entire population of MM patients was 32 months (range: 1-192 months). Among the 1046 newly diagnosed MM cases, TP53 abnormalities were found in 153 cases, and 114 of those 153 cases (64 male patients, 50 female patients) were followed and included in the analysis, with a mean age of $59.4 \pm 10.3$ years (Table 2). Among those 114 patients, 23 cases were stage I, 27 cases were stage II, and 64 cases were stage III at the time of diagnosis based on the International Staging System (ISS) (Table 2). Due to the significant effect of extramedullary disease (EMD) on survival rate reduction [23], patients' EMD statuses at diagnosis were recorded. Most patients (86.84\%) had no EMD at diagnosis (Table 2). Other medical history (hypertension, diabetes, heart disease, etc.), lifestyle factors (smoking and alcohol consumption), and clinical characteristics (neutrophils, platelet count, hemoglobin level, creatinine level, etc.) that may affect or reflect disease progression are provided in Tables 2 and 3 . Patients mainly received autologous hematopoietic cell transplantation and/or standard chemotherapies, including but not limited to bortezomib combined with dexamethasone (PD) or three-drug combinations of PD with liposomal doxorubicin or thalidomide (Table 2).

In our analysis, the OS of patients was mainly affected by age and chemotherapy. Younger age $(<60$ years old) correlated with increased OS rate compared to older patients ( $\geq 60$ years old) (median survival: 72 months vs. 39 months, $p=0.038$ ) (Figure 1A). Chemotherapy increased the median survival time from 28 months to 77 months $(p=0.029)$ (Figure 1B). However, the other major therapy received by our patients, autologous hematopoietic cell transplantation therapy, did not further improve patient survival rate ( $p=0.428$; data not shown). Other

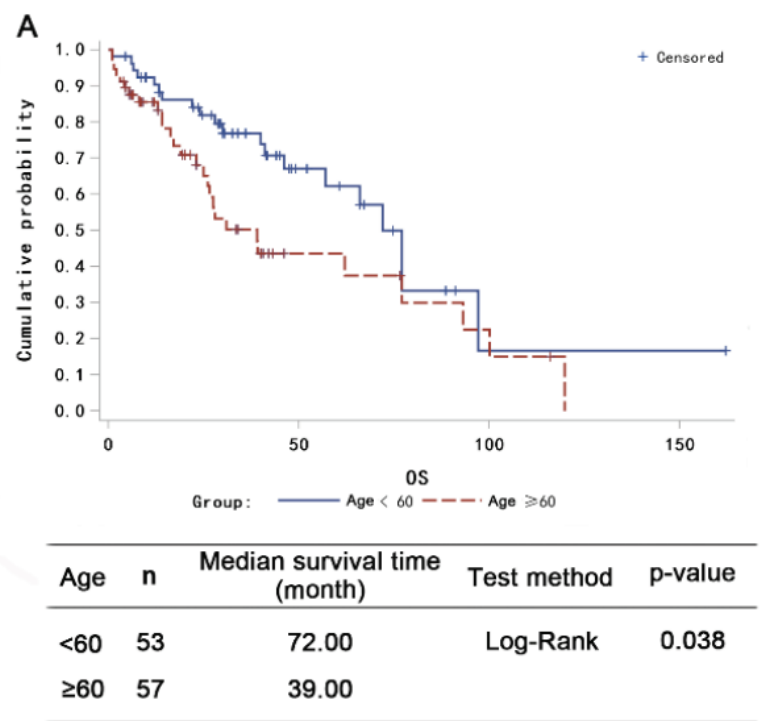

\begin{tabular}{|c|c|c|}
\hline & & n (\%) \\
\hline \multirow{2}{*}{ Gender } & Male & $64(56.14)$ \\
\hline & Female & $50(43.86)$ \\
\hline \multirow{2}{*}{ Age } & Age $<60$ & $54(47.37)$ \\
\hline & Age $\geq 60$ & $60(52.63)$ \\
\hline \multirow[t]{2}{*}{ Durie-Salmon System } & $\mid-I I$ & $14(12.39)$ \\
\hline & III & 99 (87.61) \\
\hline \multirow{3}{*}{ International Staging System } & 1 & $23(20.18)$ \\
\hline & II & $27(23.68)$ \\
\hline & III & $64(56.14)$ \\
\hline \multirow{2}{*}{$\begin{array}{l}\text { Eastern Cooperative Oncology Group } \\
\text { performance status }\end{array}$} & 0 & 55 (48.25) \\
\hline & $\geq 1$ & $59(51.75)$ \\
\hline \multirow{2}{*}{ Smoking } & No & $81(71.05)$ \\
\hline & Yes & $33(28.95)$ \\
\hline \multirow{2}{*}{ Alcohol consumption } & No & 90 (78.95) \\
\hline & Yes & $24(21.05)$ \\
\hline \multirow{2}{*}{ Hypertension } & No & 71 (62.28) \\
\hline & Yes & $43(37.72)$ \\
\hline \multirow{2}{*}{ Diabetes } & No & 97 (85.09) \\
\hline & Yes & $17(14.91)$ \\
\hline \multirow{2}{*}{ Heart disease/arteriovenous thrombosis } & No & 103 (90.35) \\
\hline & Yes & $11(9.65)$ \\
\hline \multirow{2}{*}{ Chemotherapy } & No & $18(15.79)$ \\
\hline & Yes & $96(84.21)$ \\
\hline \multirow{2}{*}{$\begin{array}{l}\text { Autologous hematopoietic cell } \\
\text { transplantation }\end{array}$} & No & $94(82.46)$ \\
\hline & Yes & $20(17.54)$ \\
\hline \multirow{2}{*}{ EMD } & No & 99 (86.84) \\
\hline & Yes & $15(13.16)$ \\
\hline \multicolumn{3}{|l|}{ EMD: Extramedullary disease. } \\
\hline
\end{tabular}

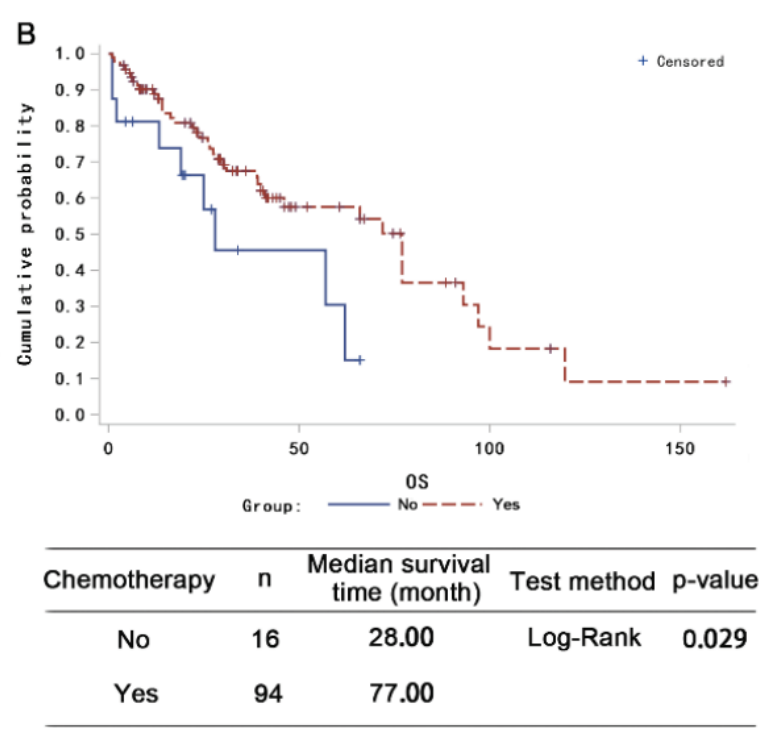

Figure 1. Factors that influence patient survival. Log-rank analysis of (A) age and (B) chemotherapy on patients' overall survival. Patient numbers are indicated on the charts. Age groups are separated based on the mean age in our patient cohorts. 
factors including gender, ISS, Eastern Cooperative Oncology Group score, smoking, and alcohol consumption did not have a significant correlation with PFS or OS rates (data not shown).

Among the 114 patients with TP53 abnormalities, 54 showed TP53 amplification and 60 showed TP53 deletion. Compared to patients with TP53 deletion, those with TP53 amplification had a higher probability of achieving complete response (Table $4 ; p=0.008$ ) and had modest PFS and OS advantages (Figures $2 \mathrm{~A}$ and $2 \mathrm{~B}$ ). When 3-year survival time was used as the cutoff in analysis, the patients who survived had a higher percentage of TP53 amplification than patients who died (mean: $61.4 \%$ vs. $40.27 \% ; p=0.034)$. The PFS and OS rates of patients with more than 51.25\% TP53 amplification (value calculated by receiver operating characteristic curve analysis; data not shown) trended more highly than those of patients with less TP53 amplification (Figures $3 \mathrm{~A}$ and 3B). Together, these data suggest that TP53 amplification plays a positive role in patient survival.

The genes and chromosomes that are commonly dysregulated in $\mathrm{MM}$ patients were also tested in these 114 patients [chromosome $1 q 21$ amplification, 4p16.3 (FGFR3), 16q23 (MAF), $\operatorname{lgH}$ translocations, abnormal chromosome counts] to show the potential effects of these common genetic dysregulations in the background of TP53 abnormality. The genomic changes in these 114 patients are summarized in Table 5 .

Overall, our data indicate that patients with four or more types of mutations in the list have PFS rates similar to those of patients with fewer than four types of mutation (data not shown). However, their OS rates trend more highly compared to patients

\begin{tabular}{|c|c|c|c|c|c|c|}
\hline Abb. & Feature & $n$ & SD & Min & Max & Median \\
\hline NE & Neutrophils $\left(10^{9} / \mathrm{L}\right)$ & 114 & 5.95 & 0.49 & 63.2 & 3.13 \\
\hline HGB & Hemoglobin (g/L) & 114 & 24.2 & 50 & 152 & 90.8 \\
\hline PLT & Platelet $\left(10^{9} / \mathrm{L}\right)$ & 114 & 89.07 & 20 & 724 & 165 \\
\hline ALB & Albumin (g/L) & 114 & 6.75 & 17.6 & 48 & 34.55 \\
\hline CR & Creatinine $(\mu \mathrm{mol} / \mathrm{L})$ & 114 & 182.09 & 30 & 1004.9 & 77.35 \\
\hline LDH & Lactate dehydrogenase (U/L) & 114 & 119.95 & 68 & 971 & 163.5 \\
\hline CA & Calcium (mmol/L) & 114 & 1.78 & 1.54 & 20.8 & 2.19 \\
\hline BTA & $\beta 2$-microglobulin (mg/L) & $112^{*}$ & 9.73 & 1.42 & 73.5 & 4.34 \\
\hline BNP & B-type natriuretic peptide & $113^{*}$ & 3659.42 & 5 & 35000 & 149.9 \\
\hline LVEF & Left ventricular ejection fraction & 114 & 6.38 & 45 & 82 & 69 \\
\hline JXBP & Plasma cell $\%$ in bone marrow & 114 & 21.48 & 1 & 93.5 & 36.25 \\
\hline
\end{tabular}
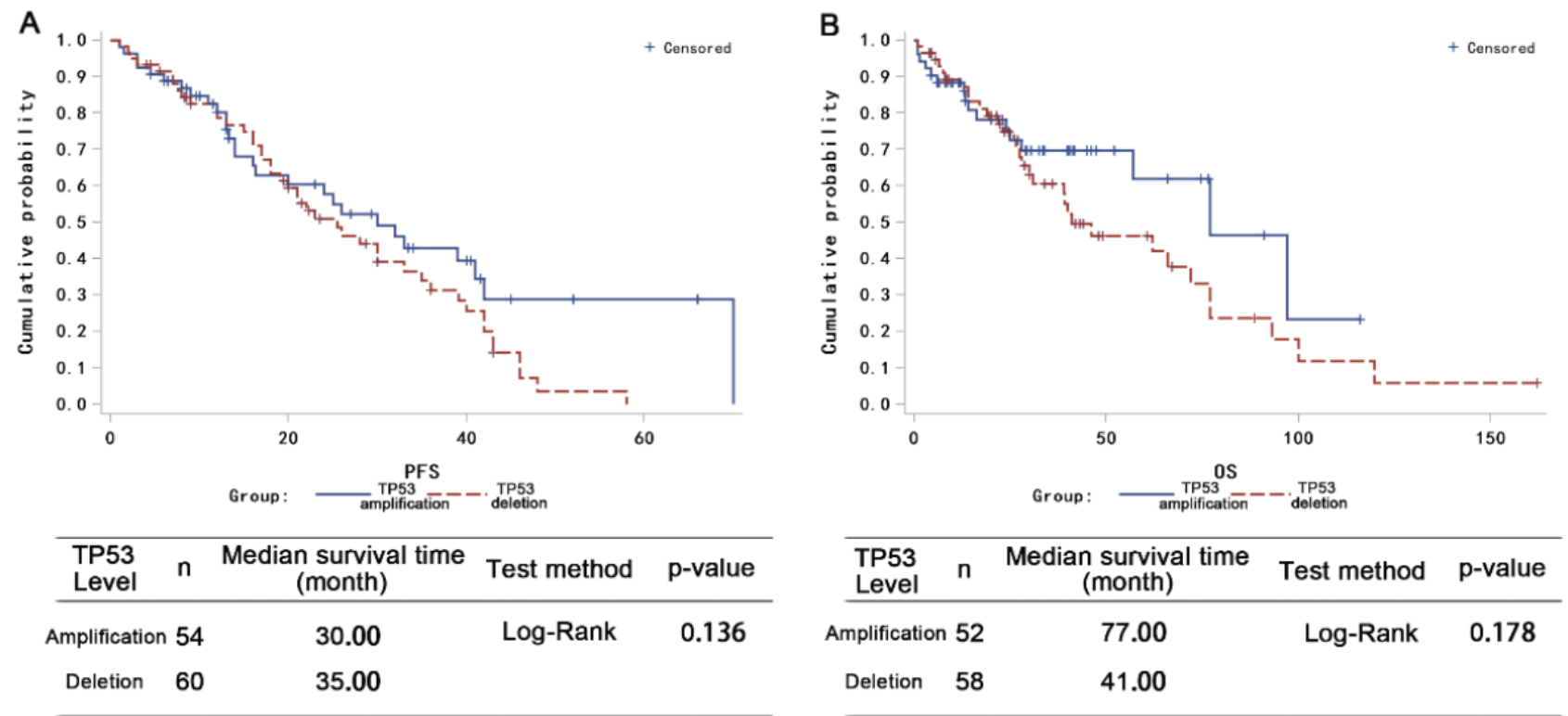

Figure 2. TP53 level affects patient survival. Log-rank analysis of the effect of TP53 amplification and deletion on (A) progression-free survival (PFS) and (B) overall survival (OS) of the patients. 
with lower mutation burden (Figure 4A). When OS analysis was performed for patients separated by TP53 status, though, no significant difference was found between patients with four or more types of mutations and patients with fewer than four types of mutations, potentially due to the low patient number in each group (Figures $4 \mathrm{~B}$ and $4 \mathrm{C}$ ). The effects of individual genetic abnormalities in the background of TP53 abnormality on OS were also tested. In our patient cohorts with TP53 abnormality, of the five genetic abnormalities (1q21, FGFR3, MAF, IgH translocations, and chromosome number changes), 1q21 amplification predicted the decreased probability of complete response (Table 4; odds ratio: 4.209), and the type of FGFR3 mutation was critical in predicting patients' PFS and OS. FGFR3 amplification yielded a fivefold increase in median survival time compared to FGFR3 deletion (100 months vs. 19 months) and a twofold increase compared to patients with normal FGFR3 (100 months vs. 41 months) (Figure 4D). We further analyzed median survival times for patients with FGFR3 amplification and normal FGFR3 as separated by their TP53 statuses. Patients with FGFR3 amplification still had significantly longer median

\begin{tabular}{|l|l|l|l|}
\hline \multicolumn{4}{|l|}{ Table 4. Risk factors involved in complete response to therapies. } \\
\hline Age & Risk factors & OR & p \\
\hline DS & Unit =1 & $1.045(0.997-1.096)$ & 0.068 \\
\hline Chemotherapy & I-I vs. III & $0.181(0.044-0.737)$ & 0.017 \\
\hline TP53 & $\begin{array}{l}\text { Amplification vs. } \\
\text { Deletion }\end{array}$ & $0.225(0.075-0.677)$ & 0.008 \\
\hline 1q21 & $\begin{array}{l}\text { Amplification vs. } \\
\text { Deletion }\end{array}$ & $4.209(1.258-14.076)$ & 0.020 \\
\hline OR: Odds ratio; DS: Durie-Salmon System. & \\
\hline
\end{tabular}

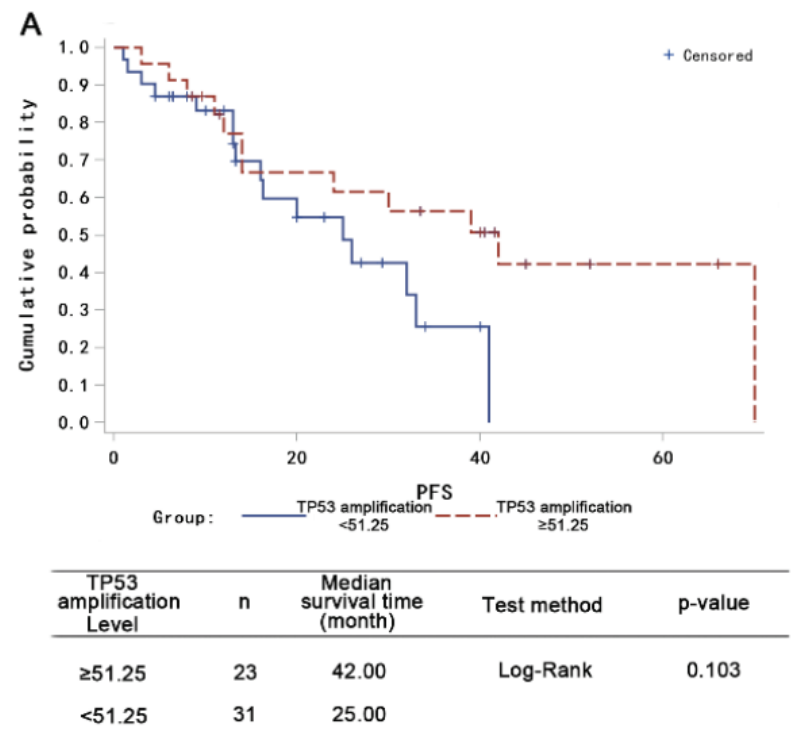

survival time in the background of TP53 amplification (Figure 4E), but not in cases of TP53 loss (Figure 4F).

These data suggest that TP53 status in combination with common mutations in MM could potentially be used to predict patient survival at the time of disease diagnosis.

\section{Discussion}

TP53 is a critical tumor suppressor and reported to correlate with MM disease progression. However, TP53 mutation is a rare

\begin{tabular}{|c|c|c|}
\hline & & n (\%) \\
\hline \multirow{2}{*}{ TP53 } & Amplification & $54(47.37)$ \\
\hline & Deletion & $60(52.63)$ \\
\hline \multirow{3}{*}{$1 q 21$} & Amplification & $84(73.68)$ \\
\hline & Deletion & $1(0.88)$ \\
\hline & Normal & $29(25.44)$ \\
\hline \multirow{3}{*}{$M A F$} & Amplification & $29(25.44)$ \\
\hline & Deletion & $24(21.05)$ \\
\hline & Normal & $61(53.51)$ \\
\hline \multirow{3}{*}{ FGFR3 } & Amplification & $32(28.07)$ \\
\hline & Deletion & $6(5.26)$ \\
\hline & Normal & $76(66.67)$ \\
\hline \multirow{3}{*}{$\lg \mathrm{H}$} & Amplification & 25 (21.93) \\
\hline & Deletion & $15(13.16)$ \\
\hline & Normal & $74(64.91)$ \\
\hline \multirow{2}{*}{ Chromosome } & $46, X Y / X X$ & 95 (83.33) \\
\hline & Other & $19(16.67)$ \\
\hline \multicolumn{3}{|c|}{ IgH: Immunglobulin $\mathrm{H}$. } \\
\hline
\end{tabular}

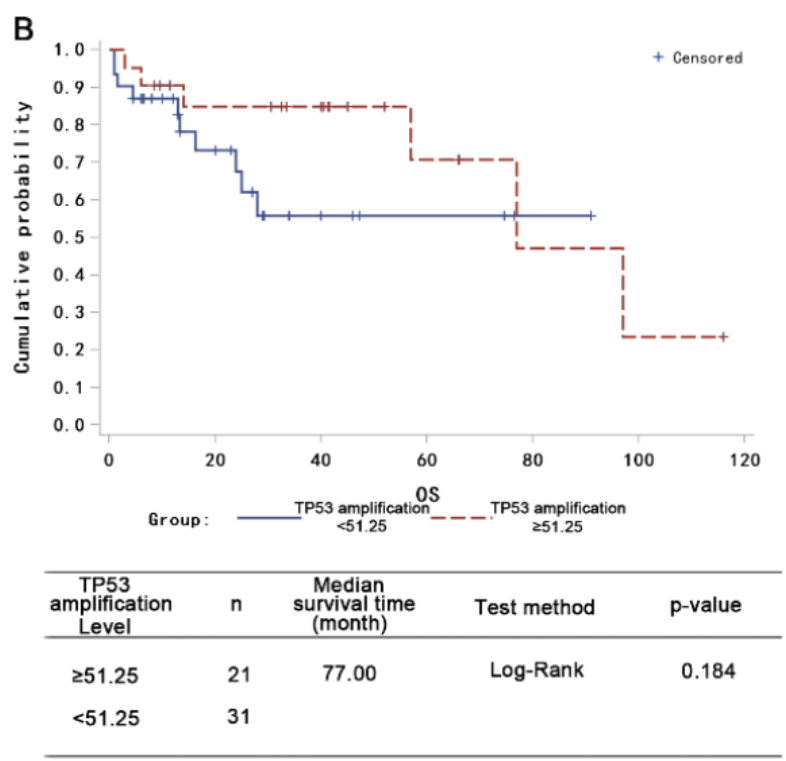

Figure 3. TP53 amplification predicts better patient survival. Log-rank analysis of the effect of the level of TP53 amplification on (A) progression-free survival (PFS) and (B) overall survival (OS) of the patients. The cutoff threshold of TP53 amplification is based on receiver operating characteristic curve analysis. 

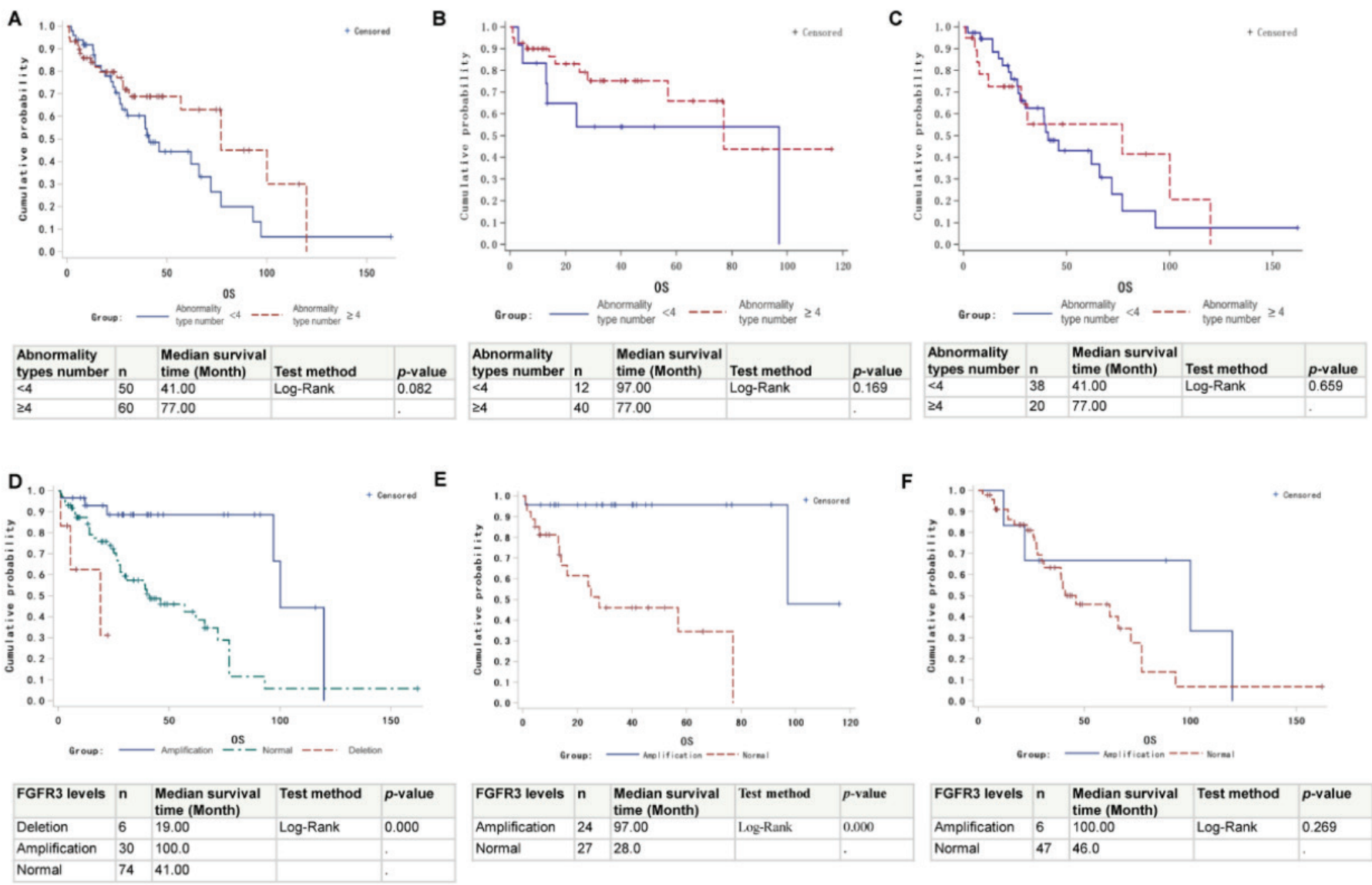

Figure 4. The ability of common mutations found in MM patients to predict patient survival among patients with TP53 abnormalities. (A) Correlation between number of genetic abnormalities and patient OS. (B) Correlation between number of genetic abnormalities and patient OS in the background of TP53 amplification. (C) Correlation between number of genetic abnormalities and patient OS in the background of TP53 deletion. (D) FGFR3 level in predicting median patient survival time. (E) FGFR3 status in predicting median patient survival time in the background of TP53 amplification. (F) FGFR3 status in predicting median patient survival time in the background of TP53 loss.

MM: Multiple myeloma.

occurrence at diagnosis, being seen in only about 3\% of newly diagnosed patients. The large patient cohorts in our hospitals provided an opportunity for us to study TP53 mutation in earlystage MM patients, which brings insight into the clinical significance of TP53 in newly diagnosed MM patients and also disease progression.

In 114 newly diagnosed MM patients with TP53 abnormalities, we found that patient age and stage of the disease were the strongest predicting factors for patient PFS and OS, with older age and later stages indicative of worse prognosis, consistent with reports from other groups [24,25]. Patients' lifestyles (smoking, etc.) and preexisting conditions (heart diseases, etc.) did not have strong effects on patient survival.

TP53 deletion is more commonly found in MM patients. In the present study we also reported a group of patients with TP53 amplification, which was associated with increased PFS and OS. The mechanism of TP53 amplification is unknown, but it could potentially be caused by the compensating of non-functional p53 protein. Among the patients with TP53 mutations, nearly half showed TP53 amplification, and TP53 amplification was a strong predictor for a complete response to therapy. Furthermore, the level of TP53 amplification $(\geq 51.25 \%)$ also showed a trend of positive correlation with patient survival rate. These data indicate that TP53, as a tumor suppressor, plays an important role in MM patient prognosis; patients with TP53 deletion at an earlier stage and patients of older ages will potentially have a decreased chance of reaching complete response when treated with standard chemotherapy and autologous hematopoietic cell transplantation therapy. More advanced and intensive therapeutic strategies are potentially needed for these patients.

As common mutations in MM patients, 1q21 and FGFR3 levels were good predictors of patient's therapy responses and OS in our cohorts. Copy number gain of chromosome 1q21 is among the 
most commonly reported genetic abnormalities in MM patients. The predictive role of 1q21 amplification in MM patients in terms of chemotherapy response and patient survival, however, is controversial. Studies have shown that 1 q21 amplification strongly correlates with bortezomib resistance, but others showed no response prediction or survival benefit for patients with 1q21 amplification $[26,27,28]$. Our data indicate that in patients with TP53 abnormalities, 1q21 amplification is a strong predictor for worse response to chemotherapy, suggesting that the study of 1q21's role in the context of TP53 mutation is of great clinical importance.

On the other hand, the $t(4 ; 14)$ translocation is associated with upregulation of FGFR3 amplification, which has been shown to correlate with poor patient survival $[29,30]$. Interestingly, in contradiction with other studies, we found that in newly diagnosed MM patients with TP53 mutation, FGFR3 levels had a strong positive correlation with patient PFS and OS. Patients with FGFR3 amplification had a nearly twofold increase in median survival time compared to patients with normal FGFR3 levels. These data suggest that FGFR3 level is a critical prognosis indicator and a potential therapeutic target in $\mathrm{MM}$ patients with TP53 mutation.

\section{Study Limitations}

One limitation of our study is that the patient number is small, due to the fact that TP53 mutation is rarely present at diagnosis. Data analysis for age or other mutation types is limited in the total population of patients with TP53 mutation and separate analysis for each feature in TP53 amplification and deletion could not be performed with statistical power. Another limitation of our study is that TP53 mutation was tested at gene level. Whether the MM patients in our cohorts had functional p53 protein in their tumors or not is unknown, which may have introduced noise to our data analysis. Addressing the functional p53 protein levels in those patients in future work could potentially help to gain more statistical power in our analysis and a better understanding of the functional role of p53 in newly diagnosed MM patients.

\section{Conclusion}

By extensive analysis of 114 newly diagnosed MM patients with TP53 abnormalities, we observed a positive correlation between TP53 amplification and MM patient survival. Further investigation of TP53 and the common mutations in MM patients will contribute to the better design of biomarkers to predict MM patient therapy response and survival.

\section{Ethics}

Ethics Committee Approval: The study was approved by the ethics committee of our hospital.
Informed Consent: All patients gave written informed consent.

\section{Authorship Contributions}

Surgical and Medical Practices: T.W.; Concept: F.Y., W.C.; Design: F.Y.; Data Collection or Processing: F.Y., T.W., A.L., Y.L., N.L.; Analysis or Interpretation: T.W., Y.L., N.L., W.C., H.W.; Writing: F.Y., W.C.

Conflict of Interest: No conflict of interest was declared by the authors.

Financial Disclosure: The authors declared that this study received no financial support.

\section{References}

1. Rajkumar SV, Dimopoulos MA, Palumbo A, Blade J, Merlini G, Mateos MV, Kumar S, Hillengass J, Kastritis E, Richardson P, Landgren O, Paiva B, Dispenzieri A, Weiss B, LeLeu X, Zweegman S, Lonial S, Rosinol L, Zamagni E, Jagannath S, Sezer O, Kristinsson SY, Caers J, Usmani SZ, Lahuerta JJ, Johnsen HE, Beksac M, Cavo M, Goldschmidt H, Terpos E, Kyle RA, Anderson KC, Durie BG, Miguel JF. International Myeloma Working Group updated criteria for the diagnosis of multiple myeloma. Lancet Oncol 2014;15:e538548.

2. Rajkumar SV. Multiple myeloma: 2014 Update on diagnosis, riskstratification, and management. Am J Hematol 2014;89:999-1009.

3. Weaver CJ, Tariman JD. Multiple myeloma genomics: a systematic review. Semin Oncol Nurs 2017;33:237-253.

4. Landgren 0, Morgan GJ. Biologic frontiers in multiple myeloma: from biomarker identification to clinical practice. Clin Cancer Res 2014;20:804813.

5. Agnelli L, Tassone P, Neri A. Molecular profiling of multiple myeloma: from gene expression analysis to next-generation sequencing. Expert Opin Biol Ther 2013;13(Suppl 1):S55-68.

6. Cowan AJ, Allen C, Barac A, Basaleem H, Bensenor I, Curado MP, Foreman K, Gupta R, Harvey J, Hosgood HD, Jakovljevic M, Khader Y, Linn S, Lad D, Mantovani L, Nong VM, Mokdad A, Naghavi M, Postma M, Roshandel G, Shackelford K, Sisay M, Nguyen CT, Tran TT, Xuan BT, Ukwaja KN, Vollset SE, Weiderpass E, Libby EN, Fitzmaurice C. Global burden of multiple myeloma: a systematic analysis for the Global Burden of Disease Study 2016. JAMA Oncol 2018;4:1221-1227.

7. Rasche L, Kortum KM, Raab MS, Weinhold N. The impact of tumor heterogeneity on diagnostics and novel therapeutic strategies in multiple myeloma. Int J Mol Sci 2019;20:1248.

8. Chesi M, Bergsagel PL. Advances in the pathogenesis and diagnosis of multiple myeloma. Int J Lab Hematol 2015;37(Suppl 1):108-114.

9. Manier S, Salem KZ, Park J, Landau DA, Getz G, Ghobrial IM. Genomic complexity of multiple myeloma and its clinical implications. Nat Rev Clin Oncol 2017;14:100-113.

10. Barwick BG, Gupta VA, Vertino PM, Boise LH. Cell of origin and genetic alterations in the pathogenesis of multiple myeloma. Front Immunol 2019;10:1121.

11. Nemec $P$, Zemanova Z, Kuglik $P$, Michalova $K$, Tajtlova J, Kaisarova $P$, Oltova A, Filkova H, Holzerova M, Balcarkova J, Jarosova M, Rabasova J, Hruba M, Spicka I, Gregora E, Adam Z, Scudla V, Maisnar V, Schutzova M, Hajek $\mathrm{R}$; Czech Myeloma Group. Complex karyotype and translocation $\mathrm{t}(4 ; 14)$ define patients with high-risk newly diagnosed multiple myeloma: results of CMG2002 trial. Leuk Lymphoma 2012;53:920-927.

12. Greslikova $H$, Zaoralova R, Filkova $H$, Nemec $P$, Oltova $A$, Kupska R, Rudolecka P, Smetana J, Pour L, Zahradova L, Krejci M, Buchler T, Adam Z, Hajek R, 
Kuglik P. Negative prognostic significance of two or more cytogenetic abnormalities in multiple myeloma patients treated with autologous stem cell transplantation. Neoplasma 2010;57:111-117.

13. Miller A, Asmann $Y$, Cattaneo L, Braggio E, Keats J, Auclair D, Lonial S, Network MC, Russell SJ, Stewart AK. High somatic mutation and neoantigen burden are correlated with decreased progression-free survival in multiple myeloma. Blood Cancer J 2017;7:e612.

14. Brady CA, Attardi LD. p53 at a glance. J Cell Sci 2010;123(Pt 15):2527-2532.

15. Gaballa S, Saliba RM, Srour S, Lu G, Brammer JE, Shah N, Bashir Q, Patel K, Bock F, Parmar S, Hosing C, Popat U, Delgado R, Rondon G, Shah JJ, Manasanch EE, Orlowski RZ, Champlin R, Qazilbash MH. Outcomes in patients with multiple myeloma with TP53 deletion after autologous hematopoietic stem cell transplant. Am J Hematol 2016;91:E442-447.

16. Chng WJ, Price-Troska T, Gonzalez-Paz N, Van Wier $S$, Jacobus $S$, Blood $E$, Henderson K, Oken M, Van Ness B, Greipp P, Rajkumar SV, Fonseca R. Clinical significance of TP53 mutation in myeloma. Leukemia 2007;21:582-584.

17. Drach J, Ackermann J, Fritz E, Kromer E, Schuster R, Gisslinger H, DeSantis M, Zojer N, Fiegl M, Roka S, Schuster J, Heinz R, Ludwig H, Huber H. Presence of a p53 gene deletion in patients with multiple myeloma predicts for short survival after conventional-dose chemotherapy. Blood 1998;92:802-809.

18. Boyd KD, Ross FM, Tapper WJ, Chiecchio L, Dagrada G, Konn ZJ, Gonzalez D, Walker BA, Hockley SL, Wardell CP, Gregory WM, Child JA, Jackson GH, Davies FE, Morgan GJ, Group NHOS. The clinical impact and molecular biology of del(17p) in multiple myeloma treated with conventional or thalidomide-based therapy. Genes Chromosomes Cancer 2011;50:765-774.

19. Thanendrarajan $S$, Tian $E, Q u P$, Mathur $P$, Schinke $C$, van Rhee $F$, Zangari $M$, Rasche L, Weinhold N, Alapat D, Bellamy W, Ashby C, Mattox S, Epstein J, Yaccoby S, Barlogie B, Hoering A, Bauer M, Walker BA, Davies FE, Morgan GJ. The level of deletion $17 p$ and bi-allelic inactivation of TP53 has a significant impact on clinical outcome in multiple myeloma. Haematologica 2017;102:e364-e367.

20. Rajkumar SV. Updated diagnostic criteria and staging system for multiple myeloma. Am Soc Clin Oncol Educ Book 2016;35:e418-e423.

21. Gao W, Li J, Wu Y, Li Y, Leng Y, Liu A, Yang G, Tian Y, Wang H, Wang G, Wu Z, Ren $Z$, Chen W. Immunoparesis recovery 1 year after ASCT is independently associated with favorable survival in patients with symptomatic multiple myeloma who undergo autologous stem cell transplantation. Ann Hematol 2019;98:1177-1184.

22. Anderson KC, Kyle RA, Rajkumar SV, Stewart AK, Weber D, Richardson P; ASH/FDA Panel on Clinical Endpoints in Multiple Myeloma. Clinically relevant end points and new drug approvals for myeloma. Leukemia 2008;22:231-239.

23. Gagelmann N, Eikema DJ, lacobelli S, Koster L, Nahi H, Stoppa AM, Masszi T, Caillot D, Lenhoff $S$, Udvardy $M$, Crawley $C$, Arcese $W$, Mariette C, Hunter A, Leleu X, Schipperus M, Delforge M, Pioltelli P, Snowden JA, Itala-Remes $M$, Musso $M$, van Biezen A, Garderet L, Kroger N. Impact of extramedullary disease in patients with newly diagnosed multiple myeloma undergoing autologous stem cell transplantation: a study from the Chronic Malignancies Working Party of the EBMT. Haematologica 2018;103:890897.

24. Chretien ML, Hebraud B, Cances-Lauwers V, Hulin C, Marit G, Leleu X, Karlin L, Roussel M, Stoppa AM, Guilhot F, Lamy T, Garderet L, Pegourie B, Dib $M$, Sebban $C$, Lenain $P$, Brechignac $S$, Royer $B$, Wetterwald $M$, Legros $L$, Orsini-Piocelle F, Voillat L, Delbrel X, Caillot D, Macro M, Facon T, Attal M, Moreau $\mathrm{P}$, Avet-Loiseau $\mathrm{H}$, Corre J. Age is a prognostic factor even among patients with multiple myeloma younger than 66 years treated with highdose melphalan: the IFM experience on 2316 patients. Haematologica 2014;99:1236-1238.

25. Kazandjian D. Multiple myeloma epidemiology and survival: a unique malignancy. Semin Oncol 2016;43:676-681.

26. An G, Xu Y, Shi L, Shizhen Z, Deng S, Xie Z, Sui W, Zhan F, Qiu L. Chromosome 1 q21 gains confer inferior outcomes in multiple myeloma treated with bortezomib but copy number variation and percentage of plasma cells involved have no additional prognostic value. Haematologica 2014;99:353359.

27. Chen D, Zhou D, Xu J, Zhou R, Ouyang J, Chen B. Prognostic value of $1 q 21$ gain in multiple myeloma. Clin Lymphoma Myeloma Leuk 2019;19:e159-e164.

28. Nemec P, Zemanova Z, Greslikova H, Michalova K, Filkova H, Tajtlova J, Kralova D, Kupska R, Smetana J, Krejci M, Pour L, Zahradova L, Sandecka V, Adam Z, Buchler T, Spicka I, Gregora E, Kuglik P, Hajek R. Gain of 1q21 is an unfavorable genetic prognostic factor for multiple myeloma patients treated with high-dose chemotherapy. Biol Blood Marrow Transplant 2010;16:548-554.

29. Kalff A, Spencer A. The $t(4 ; 14)$ translocation and FGFR3 overexpression in multiple myeloma: prognostic implications and current clinical strategies. Blood Cancer J 2012;2:e89.

30. Chesi M, Brents LA, Ely SA, Bais C, Robbiani DF, Mesri EA, Kuehl WM, Bergsagel PL. Activated fibroblast growth factor receptor 3 is an oncogene that contributes to tumor progression in multiple myeloma. Blood 2001;97:729-736. 